\title{
An Analysis of Students' Knowledge on the Structure and Function of Plant Tissues in Senior High Schools of Medan
}

\author{
Riesyatul Khairiyah Nasution \\ Student of Biology Education Postgraduate, \\ Universitas Negeri Medan \\ Email: risa.25nst@gmail.com
}

\author{
Fauziyah Harahap, Syahmi Edi \\ Biology Departement, Universitas Negeri Medan, \\ Jl Willem Iskandar Pasar V Medan Estate, Medan, \\ Indonesia
}

\begin{abstract}
The aim of this study was to determine the students' knowledge on the structure and function of plant tissues inSenior High Schools of Medan in 2017/2018. The analysis of students' knowledge can be seen from two aspects, namely: 1) an analysis of students' knowledge on the structure and function of plant tissues inSenior High Schools of Medan; 2) an analysis of students' knowledge on the structure and function of plant tissues in each State High School of Medan. This type of research was descriptive research with a quantitative approach. The study sample was 547 students in class XI-Science Program (IPA) representing 7 Public High Schools (SMAN) in Medan, namely SMAN 4 Medan, SMAN 6 Medan, SMAN 8 Medan, SMAN 10 Medan, SMAN 11 Medan, SMAN 12 Medan, SMAN 14 Medan, and SMAN 14 Medan. The research data was taken from the knowledgeof students by using diagnostic tests in the form of multiple choices. While data acquisition was analyzed descriptively. The results showed that the students' knowledge in all high schools of Medan were relatively good (76.88), meanwhile based on each school, namely the students of SMAN 6 were very good (82.24), SMAN 11 were good $(80.09)$, SMAN 4 were good (78.16), SMAN 12 were good (76.38), SMAN 14 were good (75.93), SMAN 10 were good (73.36) and SMAN 8 were good (72.03), respectively.
\end{abstract}

Keywords: knowledge, diagnostic tests, structure and function of plant tissues

\section{INTRODUCTION}

The Curriculum 2013 is a curriculum that prioritizes understanding, skill, and character education, students are required to understand material, more active in discussions and presentations and have high discipline manners. The assessment of Curriculum 2013 is focused on characters with a proportion of $60 \%$ characters and $40 \%$ academics [1]. Determination of as much as $60 \%$ of the proportion of characters shows that in this curriculum attitude values are considered important in the world of education.Knowledge is everything in our head. We are able to know something based on the experience we have. Apart fromexperience, we also know because we are told by others. Knowledge is also derived from tradition [2].
Factors Affecting Knowledge

$$
\text { a. Age }
$$

Age is the age of individuals starting from birth to several years. The more mature the level of maturity and strength of a person will be more mature in thinking and working in terms of the trust of people who are more mature will be more trusting than people who are not high enough maturity. This is a result of mental experience [3].

\section{b. Education}

The level of education means that the guidance given by someone to the development of others leads to a certain ideal. [3]. Education is an attempt to develop personality and abilities inside and outside school and last a lifetime [4]. Education affects the learning process, according to Marta [5], the higher a person's education, the easier the person to receive information.

\section{c. Experience}

Experience is the best teacher (experiential is the best teacher), the proverb can be interpreted that experience is a source of knowledge, or experience is a way to obtain a truth of knowledge. Thus personal experience can be used as an effort to gain knowledge. This is done by repeating the knowledge gained in solvingproblems faced in the past [4]. Then the results of observations of several public high school schools in Medan obtained information that the acquisition of the structure and function of plant tissues in 2016/2017 showed that the achievement of student learning completeness was only $58.94 \%$. With details of completeness in each school as follows: (1) SMAN 14 Medan 14 was in the lowest position in terms of achieving mastery learning that was only achieving learning completeness as much as $38.46 \%$ of Minimum Completion Criteria (KKM) 75. Meanwhile SMAN 8 Medan, the learning completeness was $44.55 \%$ of KKM 70, SMAN 10 Medan, the learning completeness was $45.65 \%$ of KKM 70. Furthermore SMAN 12 Medan, the learning completeness was $60 \%$ of KKM 72, SMAN 11 Medan, the learning completeness was $68.15 \%$ of KKM 75 , SMAN 4 Medan, the learning completeness was $69.15 \%$ of KKM 72 and SMAN 6 Medan was at the top position in terms of achieving learning completeness which was $72.23 \%$ of KKM 80 . 
These results indicated that many students obtained daily repeat learning outcomes below the Minimum Completion Criteria (KKM). From the data of learning completeness that is still low, it isnecessary to analyze the knowledge and attitudes as student learning outcomes.

To find out how much the level of student learning can be known through learning outcomes. Learning outcomes are internal capabilities (capabilities) which include knowledge, skills and attitudes that have become someone's personal property and allow someone to do something [6].

\section{RESEARCH METHOD}

The study was carried out from November 2017 to January 2019. The research location was in all Senior High Schools of Medan. The study sample was 547 students in class XIScience Program representing 7 Public High Schools (SMAN) in Medan, namely SMAN 4 Medan, SMAN 6 Medan, SMAN 8 Medan, SMAN 10 Medan, SMAN 11 Medan, SMAN 12 Medan, SMAN 14 Medan, SMAN 14 Medan. The sampling technique used in this study was purposive sampling. Data collection tools in the form of diagnostic tests in the form of multiple choices to determine the knowledge and completeness of students on the topic of structure and function of plant tissues in all State High Schools of Medan. The method used in this study was descriptive with a quantitative approach, which examines the condition of natural objects and describesthe knowledge and completeness of students.

\section{RESULTS AND DISCUSSION}

The Level of Students' Knowledge on the Structure and Function of Plant Tissues inSenior High School of Medan

TABLE 1. THE LEVEL OF STUDENTS' KNOWLEDGESENIOR HIGH SCHOOLS OF MEDAN

\begin{tabular}{|c|c|c|c|c|}
\hline $\mathrm{N}_{0}$ & Name of school & Avernge Value & Iuterval Percentage & Criterta \\
\hline 1 & SMS S f Satm & $x y$ & $\mathrm{k} 1 \leq \mathrm{x} \div 110 \mathrm{3}$ & Very tinal \\
\hline 2 & SBAA X 11 Med̉an & 30,10 & $81<x<30$ & Goos \\
\hline 1 & $5 \mathrm{NA} X+\mathrm{X}: 2 \mathrm{an}$ & 78.15 & $51 \leq x \leq 80$ & Geod \\
\hline 4 & SMAXYS Mrim. & 7198 & (5) $\leq x \leq 80$ & Sิ:ai \\
\hline$S$ & SMA S 14 Xedan & 75,9 & $51<X<30$ & Good \\
\hline 6 & SVAX 10 Stìn & 79,15 & $51 \times x \times 30$ & Gcod \\
\hline 7 & SMA X B X: & 72.92 & $51 \leq \mathrm{X} \leq 80$ & Geod \\
\hline $\begin{array}{l}\text { Swer } \\
\text { scluo }\end{array}$ & $\begin{array}{l}\text { of Value of Senuin High } \\
\text { Is Stadeuts in Medan }\end{array}$ & $7 \dot{\mathrm{i}}, \mathbf{8 9}$ & $61 \leq x \leq 81$ & Sinent \\
\hline
\end{tabular}

Based on the table data above, it was known that the highest average value was obtained from SMAN 6 Medan, while the lowest average value was obtained from SMAN 8 Medan. The order of obtaining the average value from the highest to the lowest value was SMA 6 Medan with an average value of 82.24 included in a very good criteria, SMAN 11 Medan with an average value of 80.10 included in a good criteria, SMAN 4 Medan with an average score of 78.16 included in a good criteria, SMAN 12 Medan with an average value of 76.38 included in a good criteria, SMAN 14 Medan with an average value of 75.93 in a good criteria, SMAN 10 Medan withan average value of 73.36 included in a good criteria and SMAN 8 Medan with an average value of 72.03 included in a good criteria. Based on these data, there are still some knowledge that students have not been able to master. The inability of students to master that part of knowledge is indicated by students' errors in answering diagnostic tests. According to Suwarto [7], diagnostic tests are conducted to find out about which concepts are weak and to find out the causes. When students do not know the discussion about the material, it means there are some things that interfere with the learning process. The thing that dominates students so that they do not know the discussion of the material is the lack of interest of students. Based on observations of researchers, students are not interested enough to pay attention to learning, because several factors include lack of material mastery/clarification explained, use of teaching methods, use of media/teaching aids and variations in learning resources used by teachers. According to Riyanto [8] who said that the principle of good learning emphasizes repetition in order to train the power that exists in humans which consists of the power of the observer, respond and remember.

The Level of Students' Knowledge on the Structure and Function of Plant Tissues in Each High School of Medan

\section{The Level of Students' Knowledge in SMAN 4 Medan}

SMAN 4 Medan was represented in class XI-IPA 7 and XI-IPA 9. SMAN 4 Medan 4 has a total sample of 80 students. The results of diagnostic test of SMAN 4 Medan students were 67.5 obtained by 3 students and included in a sufficient criteria, where $70,72.5,75,77.5$ respectively obtained by 40 students and included in a good criteria, where 80, 82.5, 85, $87.5,90$ respectively were obtained by 37 students and included in a very good criteria. The acquisition of the level of students' knowledge in average of SMAN 4 Medan was 78.16 and included in a good criteria. It was known that students who get enough criteria were 3 students and students who get very good criteria as many as 37 students. SMAN 4 Medan became a school with the third highest level of knowledge after SMAN 6 Medan. This level of knowledge is influenced by learning done in groups and presentations. Presentations made in groups make the required learning time more so the learning material must be shortened. Group percentages will reduce the teacher's time in explaining learning directly, so that not all students are able to learn from the presentation of study groups in the classroom. Thus the high error does not know the material discussion, one of which is due to the end of learning time by grouppresentations. but on the other hand there is the lack of material evaluation reinforcement at the end of the learning so that it raises ignorance and wrong concepts that students receive. According to Suryani [9] argues that evaluation in the education system is one of the activities to monitor the quality of education quality and assist the teaching and learning process in the classroom, because it requires a measuring instrument in the form of tests or questions. Students' understanding of the subject matter can be known by someone based on the evaluation results, so that meaningful information can be obtained in decision making. 


\section{The Level of Students' Knowledge in SMAN 6 Medan}

The results of the diagnostic tests of SMAN 6 Medan students were $77.5,80$ obtained by 31 students and included in a good criteria, while $82.5,85,87.5,90$ obtained by 45 students and included in a very good criteria. The acquisition of the level of students' knowledge in average of SMAN 6 Medan was 82.24 and included in a very good criteria. It was known that students who get a good criteria amounted 31 students and students who get a very good criteria amounted 45 students. One factor that supports the creation of a high level of knowledge is to use power point media that is delivered interestingly in bringing material structure and function of plant tissue. The teacher has the perception that the material structure and function of plant tissue has an abstract mechanism and is difficult for students to imagine. So it needs to be delivered in a systematic slide show. In accordance with the opinion of Notoadmodjo [10] most of human knowledge is obtained through the eyes and ears. So that the teacher must be able to present interesting learning in audio visual.

\section{The Level of Students' Knowledge in SMAN 8 Medan}

The results of the diagnostic tests of SMA Negeri 8 Medan students were 65 and 67.5 obtained by 32 students and included in a sufficient criteria, while $70,72.5,75,77.5,80$ obtained by 51 students and included in a good criteria. The acquisition of the level of students' knowledge in average of SMAN 8 Medan was 72.03 and included in a good criteria. It was known that students who get a sufficient criteria were 32 students and students who get a very good criteria were 51 students. In the learning process of material structure and function of plant tissues, the teacher gives the material using the lecture method with the help of power point media. However, the level of knowledge obtained by students of SMAN 8 Medan was far below that of SMAN 4 Medan 4 and SMAN 6 Medan students. Students have low interest and motivation and external factors namely the learning method used by the teacher moreoften the lecture method. According to Jatmiko, et al. [11] stated that students' interest in learning was influenced by three aspects, among others: students' attention when the teaching and learning process took place, students were happy, curious about students, classes, friends, and schools. Treating the same treatment at the school but obtained a different level of knowledge, it is known that the factors that most influence the level of knowledge of students are factors that originate within the students themselves that affect the low level of knowledge.

\section{The Level of Students' Knowledge in SMAN 10 Medan}

The results of the diagnostic tests of SMAN 10 Medan students were 65 and 67.5 obtained by 16 students and included in a sufficient criteria, while 70, 72.5, 75, 77.5 obtained by 46 students and included in a good criteria. Furthermore, 80, 82,5, 85, 87,5, 90 were obtained by 7 students and included in a very good criteria. The acquisition of the level of students' knowledge in average of SMAN 10 Medan students was 73.36 and included in a good criteria. There were 16 students who get a very good criteria amounted 7 students. SMAN 10 Medan students had 66,20\% in the type of error did not know the material discussion and $33.80 \%$ in the wrong type of misconception. This showed that more students did not master the subject matterthan the wrong concept. The teacher delivered the learning material using the lecture method, so that based on the observations of the researchers the factors that most influenced the level of knowledge of the students included the students' interests and motivations. The lack of interest and motivation of students in learning can be seen by not focusing students on the learning process. According to Slameto [12] revealing learning is a complex activity that is influenced by various internal and external factors.

\section{The Level of Students' Knowledge in SMAN 11 Medan}

The results of diagnostic tests of SMAN 11 Medan were $72.5,75,77.5,80$ obtained by 57 students and included in a good criteria, while $82.5,85,87.5,90$ obtained by 20 students and included in a very good criteria. The acquisition of the level of students' knowledge in average of SMAN 11 Medan was 80.10 and included in a good criteria. It was known that students who get a good criteria amounted 57 students and students who get a very good criteria amounted 20 students. Students have the most difficulty in distinguishing the characteristics of various adult plant tissues and identifying various types of tissue making up organs in monocot and dicot plants. Someone who understands a concept, then he will describe it correctly and can provideexamples that are relevant to the concept. If students only give a definition, it does not mean that the student has understood the concept. Difficulty learning to understand a concept in the field of biology is the difficulty of connecting one concept with another concept that is interrelated [13].

\section{The Level of Students' Knowledge in SMAN 12 Medan}

The results of diagnostic tests of SMAN 12 Medan students were $65,67.5$ obtained by 17 students and included in a sufficient criteria, while $70,72.5,75,77.5,80$ obtained by 54 students and included in a good criteria. Furthermore, 82.5, $85,87.5$ obtained by 9 students and included in a very good criteria. The acquisition of the level of students' knowledge in average of SMAN 12 Medan was 76.38 and included in a good criteria. It was known that students who get a sufficient criteria were 17 students and students who get a very good criteria amounted 9 students. SMAN 12 Medan became a school with the fourth highest level of students' knowledge after SMAN 4 Medan 4. Biology teachers convey the material of structure and function of plant tissues using group discussions and presentations. Then in group presentations make the learning time more than evaluating and strengthening the material. So that at the end of the learning will bring up a little knowledge about thediscussion of material and wrong concepts received by students. According to Rusman [14] student learning activities include physical and mental activities and produce changes in values or positive attitudes in him with the guidance and responsibility of the teacher as a guide and a good source of learning and carried out through processes that are planned and 
implemented as a system to achieve learning outcomes optimal.

\section{The Level of Students' Knowledge in SMAN 14 Medan}

The results of diagnostic tests of SMAN 14 Medan were $70,72.5,75,77.5,80$ obtained by 70 students and included in a good criteria, while 82.5 was obtained by 5 students and included in a very good criteria. The acquisition of the level of students' knowledge in average of SMAN 14 Medan students was 75.93 and included in a good criteria. It was known that students who get a good criteria amounted 70 students and students who get a very good criteria amounted 5 students. SMAN 14 Medan became the third lowest level of students' knowledge after SMAN 10 Medan 10 and SMAN 8 Medan. Biology teachers convey the material of structure and function of plant tissues by using group discussions and presentations as well as learning in SMAN 12 Medan. Based on the observations of the researchers during the learning process by conducting grouppresentations in the classroom there are still many who are making noise not wanting to see other friends in class presentations and at least asking questions. In line with Nasution [15] argues that as a teacher of education the teacher must be able to master the classroom conditions so as to create a pleasant learning atmosphere, to produce a quality learning process, a teacher needs a good learning method, which is able to have a positive impact on student learning outcomes, so that teachers need the ability to apply learning methods that are in accordance with the characteristics of their students.

\section{CONCLUSION}

The level of students' knowledge on the structure and function of plant tissues in all Senior High Schools of Medan was to represent 7 Public High Schools in a good criteria. The level of students' knowledge on the structure and function of plant tissues in each high school in Medan, namely SMAN 4, SMAN 8, SMAN 10, SMAN 11, SMAN 12, and SMAN 14 Medan, respectively was included in a good criteria, while SMAN 6 Medan was in a very good criteria. This is because the learning methods used by teachers SMAN 6 Medan are very varied, then the students' interests and motivations for learning are very high.

\section{REFERENCES}

[1] Aji, N. 2014. The Development of Redox Reaction Learning Teaching Materials Sets, Constructivist Oriented. Journal Science Education, 2(1): 1-10.

[2] Prasetyo. 2007.Quantitative Research Methodology. Jakarta: PT. King.

[3] Nursalam. 2001.Metodologi Riset Keperawatan. Jakarta: Infomedika.

[4] Marta, I.B. 1997. Educational Relationship with Information. Jakarta: Balai Pustaka.

[5] Notoatmodjo. 2003.Health Education and Behavior. Jakarta: RinekaCipta.

[6] Sumarno. 2011. Contextual Learning to Improve Motivation and Learning Outcomes of Lectures Evaluation of Learning at the University of Riau's Fkip Economic Education Students. University of Riau Education Journal, 4(1): 60-68.

[7] Suwarto. 2013. Development of Diagnostic Tests in Learning. Yogyakarta: Student Library.

[8] Riyanto. 2012. Principles of Learning. Jakarta: Rineka Cipta.

[9] Suryani, Y., E. 2017. Mapping of Empirical Quality of Semester Final Exam Questions in High School Indonesian Subjects in Klaten Regency. Journal of Educational Research and Evaluation, 21(2): 142-152.

[10] Notoatmodjo. 2007. Promotion of Health and Behavioral Sciences. Jakarta: Rineka Cipta.

[11] Jatmiko, A. Maridi., Ariyanto, J. 2013. Application of Cooperative Integrated Reading And Composition Model Accompanied by Biological Comic Media to Increase Student's Interest in Biology in Class Vii-A Students of Public High School 14 Surakarta in 2011/2012.Journal of Biology Education, 5(1): 15-25.

[12] Slameto. 2010. Learning and the Factors that Affect It. Jakarta: Rineka Cipta.

[13] Hidayatussaadah, R., Hidayati, S., Umniyatie, S. 2016. Identification of Learning Difficulties of Students in Archaebacteria and Eubacteria Materials in SMA Negeri 1 Muntilan. Journal of Biology Education, 5(7): 1-10.

[14] Rusman. 2014. Learning Models (Developing Teacher Professionalism). Jakarta: Raja Grafindo Persada.

[15] Nasution, M., K. 2017. Use of Learning Methods in Improving Student Learning Outcomes. Study Practice: Educational Scientific Journal, 11 (1): ISSN 1978-8169. 